\title{
The revelations of Revelation: The book that fits, even when it does not
}

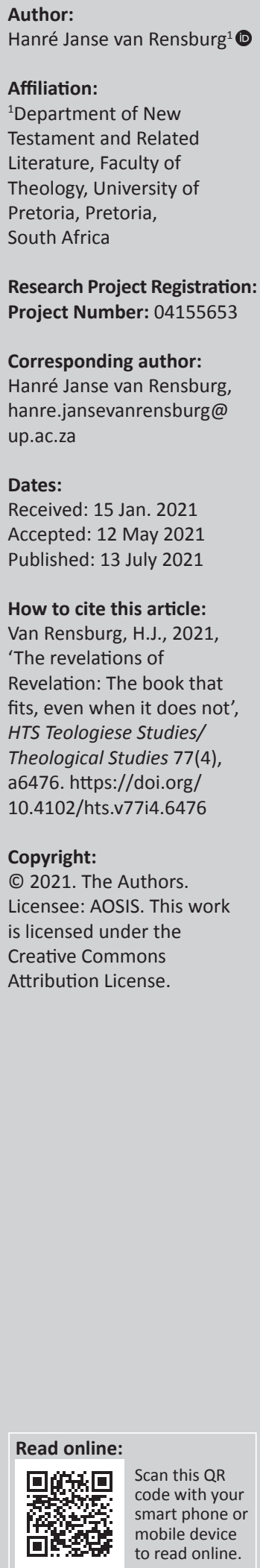

The coronavirus disease 2019 (COVID-19) pandemic has again confirmed our obsession with, and misuse of, the Book of Revelation. Of course, this is definitely not the first time that Revelation's themes and imagery have been pulled out and used to try and explain the current situation. In fact, the Book of Revelation is well-known as 'the' book of the New Testament where information about the present as well as the future can be found. Unfortunately, in situations like these, people simply do not bother to draw from the reservoir of experiences on which the author of Revelation naturally expected his hearer or reader to draw. This phenomenon is made worse by the fact that the primary study of the text has moved into the academic institution and, by inference, away from the faith movement. This may make earnest scholarly biblical study of the Apocalypse seem irrelevant to the general concerns of the faith community and the world. But the Book of Revelation does provide an indispensable resource for helping Christians conceive of their place in the contemporary world and meditate on the role the church is to play in a modern, secular society. John's Apocalypse is not a mere nostalgic trip down memory lane; it is a form of anamnesis or recollection - in recalling or performing the narrative, the past is made physically present. By way of a performative reading of the Book of Revelation, this article makes use of a more practical exegetical dimension.

Contribution: This method brings the Apocalypse as New Testament text back into the life of the community of faith it belongs to and should be performed in, thus also increasing the usage and impact of the Book of Revelation in the faith community.

Keywords: the Book of Revelation; COVID-19; crisis; the Apocalypse of John; apocalyptic literature; performative text; anamnesis; practical exegesis; significant doings; effecting change.

\section{The revealing nature of crisis}

There is nothing quite like a crisis to expose the deeply held preconceptions that shape each one of our beliefs, that drive our behaviour and that, ultimately, shape our understanding of the world and our place in it. When that crisis is a seemingly uncontrollable pandemic engulfing the whole world, then it is not only our personal strengths and weaknesses that are laid bare, but also the fragile and (oftentimes) dysfunctional strings that hold our societies together. Now, whilst the coronavirus disease 2019 (COVID-19) pandemic has and continues to reveal the many cracks that exist in our personal lives and in our societies, for the purposes of this article, I will only be focusing on one - our obsession with, and misuse of, the Book of Revelation. Its words and symbols have entered into everyday vocabulary to give expression to human hopes and fears, and human aspirations and tragedies. In an age of upheaval and transformation, they evoke a vibrant response in the minds of men and women.

Whether you are watching or reading the news, browsing your social media feeds, or listening in on or participating in conversation, you will quickly find that all of these are dominated by themes taken directly from the Apocalypse:

- COVID-19 is the beginning of the end of the world (the real one this time) and of God's final judgement.

- The antichrist has variously been identified as Donald Trump, Bill Gates (who is also viewed as Satan himself, depending on who you talk to), the World Health Organisation and China, amongst the most prominent.

- Doing things like obeying health and safety regulations put in place by wearing a mask, maintaining social distance and adhering to lockdown regulations where applicable are either

Note: Special Collection: From timely exegesis to contemporary ecclesiology: Relevant hermeneutics and provocative embodiment of faith in a Corona-defined world - Festschrift for Stephan Joubert, sub-edited by Willem Oliver (University of South Africa). 
the mark of the beast or are preparing you for receiving the mark of the beast when you are vaccinated with the COVID-19 vaccine by dumbing down your critical faculties and testing your willingness to submit without question.

- The number of the beast can easily be found in the various vaccine numbers when playing around with them a little - for example, 060606 is clearly just an attempt to 'hide' 666.

- Then there is also the terror surrounding the deployment of 5G technology, which ties into all of this as the way in which we will be controlled once we have been vaccinated

The fact that the pandemic has resulted in the entire world coming to a standstill, resembling a scene from some Hollywood disaster movie, has only added fuel to these fires.

Of course, this is definitely not the first time that Revelation's themes and imagery have been pulled out and used to try and explain the current situation. In fact, the Book of Revelation is well-known as 'the' book of the New Testament where information about the present as well as the future can be found, as it is believed to provide detailed applications to contemporary persons and events. In several respects, the Apocalypse of John is an anomaly - it is couched in obscure language, filled with strange visions, fantastic imagery, amazing events and intriguing numbers without any clear meaning. Along with its poetry, its subject matter is a big reason for its appeal - it deals with cruelty and disloyalty, with courage and faithfulness. It speaks of the last days, the promise of rewards and punishments, and the hope of a new heaven and a new earth. It is an extraordinarily complex literary composition of immense learning, containing meticulous literary artistry, creative imagination, political critique and theology. Even where its meaning is obscure it commands attention, and its very mysteriousness is a source of attraction. This has meant that, in the history of Christian interpretation, few biblical books can claim such unique and complex fortunes as the Apocalypse of John. And indeed, Revelation's vivid imagery has resulted in it probably suffering from more of a 'caricaturing' than any other New Testament document.

Throughout history, relevance-seeking Bible readers have looked for contemporary social 'signs of the times' that might be made to make fit the scenes of Revelation, thus demonstrating what is soon to happen in our own historical period. Such ethnocentric and anachronistic readings of the New Testament - and of the Apocalypse specifically - are quite common, and result from the fact that readers (most often) use scenarios rooted in their contemporary social experience to envision what they read in the New Testament. The Apocalypse is regularly subjected to this type of predetermined approach, and it is especially in times of crisis that it flourishes (Hagner 2012:746). Readers do this in an attempt to assuage the fear and the uncertainty surrounding them and their circumstances. Unfortunately, in situations like these, people simply do not bother to draw from the reservoir of experiences on which the author of Revelation naturally expected his hearer or reader to draw. This has a direct effect that, for better or worse, we then read ourselves and our world back into the document in ways we do not even suspect. Awareness of such re-contextualisation is critically important for students of the Book of Revelation. Otherwise - with reader and writer coming from mutually alien social systems - non-understanding or, at best, misunderstanding will be the rule (Malina \& Pilch 2000:22). The Apocalypse was not written to satisfy human curiosity about end-time matters (Hagner 2012:746). Indeed, if anything, the whole of the New Testament is reluctant to disclose details about the end - see, as examples, Mark 13:32 and Matthew 24:36.

This phenomenon is made worse by the fact that, although in earlier times most scholarly writers on the Apocalypse were clergy or leaders of reform movements who were eager to show that the book spoke to the issues of their own times (Wainwright 1993:157), from the 19th century onwards, the bulk of scholarly work has been done in universities and colleges. The danger of this situation - the movement of the primary study of the text into the academic institution and, by inference, away from the faith movement - is that it may make earnest scholarly biblical study seem irrelevant to the general concerns of the faith community and the world (Wainwright 1993:158).

It is with this in mind that I suggest the method I make use of in this article. My aim is to help the faith community feel more included in the study of the Book of Revelation once again. I will attempt to add onto the existing strong exegetical and critical scholarly foundations, laid by the academic community, a more practical exegetical dimension. By adding this dimension, the idea is to bring the Apocalypse as New Testament text back into the life of the community of faith it belongs to and should be performed in. By using existing scholarship on the Book of Revelation $^{1}$ as this method's foundation, I hope to ensure that the suggested performance of the text in the faith communities of today is an exegetically responsible one.

\section{Imaginative participation results in transforming actuality}

As demonstrated earlier in the texts, the Apocalypse appeals to people who believe themselves to be in crisis. Even when their fears are unjustified, they may experience real distress. Few men and women, if any, are free from the fear of war, persecution, injustice or personal tragedy. Many of them feel themselves to be threatened, even when their lives outwardly appear to be untroubled. In this frame of mind, they turn to the Apocalypse. All of these factors that attract people to the

1 Based on the work of scholars such as, for example, Aune $1997,2005,2006$. Bar 2010; Bauckham 1993; Bauckham and Hart 1999; Court 2000; Farrer 1949; Guthrie 1987; Hagner 2012; Jones \& Sumney 1999; Knight 1999; Maier 2002; Moore 1995; 1987; Hagner 2012; Jones \& Sumney 1999; Knight 1999; Maier 2002; Moore 1995; Pilch 1978; Pippin 1999; Prévost 1993;
and Wainwright 1993 to name a few. 
book today were present when it was written (see e.g. Barr 2010:632-639; Brown 1997:802-809; DeSilva 2004:893-905; Du Rand 2007:72-101; Hagner 2012:747-748, 760-775; Schnelle 2009:751-772). The churches were either suffering persecution or living in fear of it. Conflict was a real danger, whether with the Roman Empire or the Jewish synagogues. Some of the congregations that John addressed were torn by ecclesiastical controversy. Poverty, slavery and class distinction caused social unrest. The world had a full quota of natural disasters - famines, earthquakes and volcanic eruptions. People believed themselves to be in a situation of crisis. These conditions were present in the first century, and have been present ever since.

This is important because, as Aune (2005:244) himself says, ' $[d]$ espite the ways in which the biblical apocalypses have been abused at various times throughout Christian history... Revelation has important positive theological contributions to make to the modern church'. But, although the Apocalypse does raise important issues that theology seeks to deal with - issues of eschatology, ecclesiology and Christology - it also raises many other themes, such as the meaning of God's sovereignty, the nature of evil and the role of humans in establishing God's rule in the world (cf. Aune 1997:lxxii1xxc). In each of these cases, the Apocalypse does not so much teach a doctrine as tell the story in a way that implies certain conclusions. Yet, however much theology may wish to explain and resolve these issues, John never does (Barr 2010:648). Another way of looking at this is the following: Although the last part of Revelation is about the future, it does not present a more detailed prediction of future events, but rather a more basic and significant message concerning the sovereignty of God and the consummation of God's plan of salvation (Hagner 2012:746). The end of the last book of the New Testament deliberately corresponds to the opening book of the Bible. Like bookends, Genesis and Revelation enclose the library containing the story of salvation history. In this way, the Apocalypse demonstrates that eschatology corresponds to protology as fulfilment does to promise (Hagner 2012:746).

It is for these reasons that the present study's hypothesis is that, in the Book of Revelation, we have an indispensable resource for helping Christians conceive of their place in the contemporary world and meditate on the role the church is to play in a modern, secular society. This is so because, from start to finish, the Book of Revelation is a call to Christian discipleship. Whilst historically it has fuelled end-time speculation, it has also been a resource for critical appraisal of the state, the relationship of Christians to political culture and the place of Christian witness in society (Maier 2002:x). John's Apocalypse is not a mere nostalgic trip down memory lane; it is a form of anamnesis or recollection (Maier 2002:19). Insofar as the medium of communication in antiquity was predominantly oral, and even written texts were recited orally to communities of people, it will be necessary for New Testament interpretation to shift and expand its focus from written texts in themselves to (oral) communication as interactive and the context(s) in which it happened (Horsley 2011:126). Just as writing was embedded in wider oral communication, so particular texts, orally performed and/or written, were embedded in wider cultural tradition(s) and collective social memory, which thus become all the more important for our interpretation. Furthermore, insofar as oral and/or written texts (like the 'oral traditions' behind them) were used in repeated recitation and application in communities and their contexts, interpretation would be appropriately focused on their cultivation and not their mere transmission. In recalling/performing the narrative, the past is made physically present. For John, the death of Jesus is, of course, a past historical event, but its reality is present and its effects are to be felt now. The author admonishes his audience to live in a present story - most evident in John's repeated modulations in terms of tense (e.g. Rv 1:5 ' $\lambda v ́ \sigma \alpha v \tau \iota^{\prime}$ [releasing] to Rv 7:14 ' $\varepsilon$ ' $\pi \nu v v \alpha v$ ' [they have washed]; Rv 12:13 'є் $\beta \lambda \eta \dot{\eta} \theta \eta$ ' [he had been thrown down] vs. Rv 12:15 'ع $\beta \alpha \lambda \varepsilon v^{\prime}$

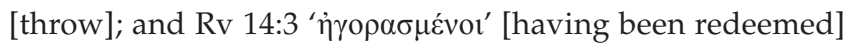

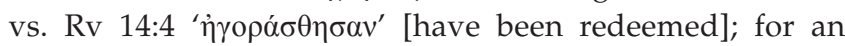
in-depth and detailed study of this aspect of the Book of Revelation, refer to Mathewson 2010). This wedding of tenses turns the Apocalypse into a subversive piece of memory-work - the Apocalypse deploys memory to recreate the present through recollection. Anamnesis invests the present with renewed significance, for the present now carries the past.

'Let anyone who has an ear listen to what the Spirit is

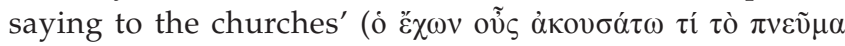

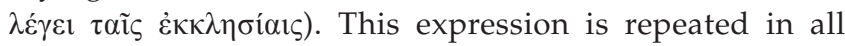
seven of the letters to John's churches in Asia Minor (Rv $2: 7,11,17,29 ; 3: 6,13,22)$. It is seldom studied because it is assumed to be a catchphrase associated with these coded secret messages. But the reverse is the case, as Enroth (1990) demonstrates:

The Hearing Formula is an invitation and an encouragement to hear. It underlines what should be heard and how it should be heard, and what follows from hearing aright ... It is openly directed towards the communities mentioned in the letters, who in fact represent the whole church ... The Hearing Formula is positive, for it does not contain the idea of judgement or of hardening. On the contrary, it underlines the promise and possibility of salvation. (pp. 598-608)

It is the hypothesis of the ongoing research on which this article is based that every aspect of the Book of Revelation which describes the church - that is, worship and witness, being Christ-centred, coping with fierce opposition, showing a spiritual effectiveness, and working out one's ministry in terms of priesthood and prophecy - is capable of a direct translation into the situation of today's church in the modern world. This is so because language does not simply describe the world but may instead (or also) function as a form of social action. This power of language to effect change in the world is known as 'performativity' (first introduced by Austin 1962:4-11, fleshed out and elaborated on by Searle 1969). The result is that Revelation still offers significant and 
positive ideas for those with ears to hear and cannot be dismissed as an outdated, self-conscious irrelevance.

\section{Defining the process of a performative reading}

What follows in the rest of this article will be an exploration of the possible performative function of the Apocalypse in its original context. To be able to do this, it will be necessary to understand special communications as interactive and contextual, a far more complex undertaking than considering the meaning of written texts as artefacts, as we have been trained to do (Horsley 2011:144). Adequate appreciation and interpretation would then require not just a sense of the rhetorical tone and rhythm of the respective speeches, but a sense of the hearers' life circumstances, their historical situation, and the cultural tradition in which they hear and respond to the speeches. So, in order to hear and interpret New Testament texts, it is necessary to discern the contours of the text, to determine the historical context of the community of the interactive hearers and to know as much as possible about the cultural tradition out of which the voiced texts resonate with the hearers (Horsley 2011:145).

With this performative reading, it is about rediscovering the Book of Revelation's importance for the Christian community. In a sense, it is about claiming it back from its assimilation (disappearance?) into Western culture. It is about finding those ideas and elements within the text of the Apocalypse that can be made use of in the community of faith's communal expression, so as to affect both conscious and sub-conscious change. Here it is important to recognise that this change is not brought about by being able to answer life's difficult questions, for, in practice, formal theological ideas are not used in a deductive manner. Realistically, individuals hold opinions, beliefs and values that are partial, fragmentary and changing. These opinions and beliefs are constantly interfusing with the activities, rites and manifold endeavours of life. So it is rather about recognising that we, as people, hunger and thirst for significant 'doings'. And that, through participation in these significant 'doings' - that is, performative rituals or 'rites of intensification' - our understanding of, our perspective on, and our emotions regarding life's difficulties are changed. This change happens almost spontaneously, because of the conscious and subconscious interaction that participation in performative ritual brings into being. It will be demonstrated that participation in performative ritual has the power to unravel the ultimate problems and paradoxes of our existence - not by providing all the intellectual answers we desire - but through participation in periods (rituals) where action and awareness merge. In the elements of performative ritual, and our participation therein, we experience the high and explicit sanctification of life's most primary concepts. The immediate and lasting effect of this being an embodied and lived experience of the preservation of the world's wholeness in the face of fragmenting and dissolving forces. Through participation, hope can be fused into our sub-conscious, from where it is able to affect our conscious daily living in a much more powerful way than merely thinking about it can ever achieve.

Thus, this article will be dedicated to exploring the possibilities opened up with the help of the performative method when studying the kind of reading we do to function in the world, day-to-day. This study will be focused on possible ways in which the text of Revelation as apocalypse could be used in this ritual functional way to re-create and strengthen hope in today's faith communities. The hypothesis is that, by way of a performative reading of the Book of Revelation, it can belong once again to the community of faith from whom it was estranged. It is hoped that, by giving the book and its contents back in this way, it becomes possible for Revelation to be a book that gives meaning to life when people cannot find meaning on their own. A book and rituals that allow people to consciously and sub-consciously - experience the good in the seemingly horrible, especially when it comes to their misfortune.

Such a modern hermeneutic theory thus insists that the meaning of a work is primarily what it means to the reader. Here it is important to remember that a pluralism of method can turn into an ideological pluralism in which there are no objectively correct answers, only a range of subjective responses. To prevent this, the contributions of the author and of their situation to what is said, as well as the ways in which this handles and is handled by the continuity of traditions, must still retain some significance, if not decisive control, in questions of meaning. Revelation's vision of an alternative world derives power from the actual contrast with the socio-political realities that gave it birth (Court 1994:19). For literary tensions and theological dialectic to be understood fully, historical questions must remain part of the interpreter's task.

\section{Revelation as apocalypse}

As was stated earlier, the article concentrates on what new insight might be gained from, and contribution made to, the current study and understanding of the Book of Revelation by focusing on the performative aspects of the text. This can only be accomplished when considering Revelation as literature born from an apocalyptic worldview, for it is in the very nature of apocalyptic thinking to seek to create a sense of crisis.

An apocalyptic worldview is characterised by a stark contrast between supranatural forces of evil and forces of good lining themselves up against one another in a final cosmic conflict that spreads throughout the whole earth, followed by the overthrow by God or the forces of good (Tabor, Boyer \& Collins 2014). It is a worldview that:

[F]ocuses on cryptic revelations about a sudden, dramatic, and cataclysmic intervention of God in history; the judgment of all men; the salvation of the faithful elect; and the eventual rule of the elect with God in a renewed heaven and earth. (Brittanica 2006) 
It is an attempt to take individual circumstance and put it into a larger, universal history (Cohn, Edwards \& Campion 2014). This apocalyptic religious worldview was not the only worldview in existence at the time - the first known manifestations of 'scientific' thinking in the West appeared amongst the ancient Greeks, but they were much more concerned with the nature of reality than with predicting the future. Greek thinkers rejected myth in favour of philosophy in the sixth century BCE, prompting them to view the cosmos as reasonable and balanced as the society in which they lived (Vox 2017). Pre-Socratic Greek philosophers, such as Thales, wondered about the fundamental composition of all creation. This query led to speculation about the origins of the universe and of life itself. In the area of human evolution, some scholars have argued that the ancient Greeks had a rudimentary notion of evolution. Greek cosmology envisioned a cyclical universe, where destruction would be followed by rebirth in an endless pattern (Vox 2017). The universe was thus viewed as regular and eternal.

The rejection of the validity of the apocalyptic worldview, and with it also its applicability, came as one of the results of the Enlightenment. With the Enlightenment, the Christian ideas that life had a discernible purpose, humans should behave in a particular and universal way or events unfolded according to a certain design were rejected (Vox 2017). Philosophers now sought to describe the workings of events and actions without assuming an overarching plan, and the description of physical processes replaced assertions of God's purpose in explanations of nature. According to the modernism that developed from the Enlightenment, the future belongs to harmony, well-being and enlightenment. In this myth of progress, things such as disease, ignorance, superstition, violence, prejudice and rapaciousness are passing away (Greydanus 2019), with the new 'prime mover' expected to lead the world into the global empire of milk and a conglomerate composed of technology, markets and corporations, governments and military (Keen 2007:30).

For this reason, it has become almost standard practice in academic research on apocalyptic material to, after defining the worldview characteristic of apocalypticism, then discount the worldview and any conclusions that can be drawn from it as inapplicable. The continuing value of apocalyptic material cannot be drawn from anything resulting from its worldview. But to say this is to deny two important phenomena:

1. Since the 19th century, the Western world has seen itself in a constant state of crisis in terms of rapid secularisation, industrialisation and urbanisation, and it would seem that the notion of an apocalypse is still relevant. But religious visions of the apocalypse do not seem to have relevance to the largely secular society they would have been addressing. Something new, immediate and drastic was needed, which would supply the society with the energy to withstand the crisis of a secular world (Thompson 1985). Hope that science would heal the world has given way to gnawing anxiety over climate change, loss of environment and micro-plastics in the ocean. Civil-rights optimism for a post-racial future has succumbed to an increasingly pessimistic understanding of racism as a perennial dynamic embedded in social structures and institutions. The Internet, once hailed as the ultimate engine for the dissemination of knowledge, has become a hothouse where even the most bankrupt conspiracy theories and counterfactual claims fester (Greydanus 2019). This has led to the development of the secular apocalypse. The secular apocalypse differs from the religious apocalypse in that the Last Judgment, which was to be carried out by God and would be off this earth and beyond time, has become something wrought on this earth by human beings against human beings (Cohn et al. 2014). The three greatest mythic-political systems that promised an end to ordinary history and the dawning of utopia (i.e. secular apocalypses) are the communist dream of a classless society; the fascist vision of a thousand-year Reich and the American version of the myth of progress (Keen 2007:30). In its secular manifestations, the apocalyptic worldview has influenced political ideologies and the public perception of the state of the economy and the environment, and it has become a staple of mass popular culture (DiTommaso 2019). So even in our present-day society, where religion has been left behind, the apocalyptic worldview still functions.

2. In every century since New Testament times, Christians have been convinced that they are living in the last days. The vast majority of Christians throughout history have believed that the Revelation of John and the other apocalyptic books of the Bible reveal the imminent end of the present age and the dawning of the age to come (DiTommaso 2019). Today, a vast number of modern people still believe in the biblical apocalypse, and believe that the events predicted in the Book of Revelation will come to pass (Keen 2007:29). The apocalyptic message and the apocalyptic ideas of the Book of Revelation are believed to be just as relevant to the faith communities of today. This means that removing discussion of the apocalyptic worldview and its possible impact is to deny elements that are still central to Christian beliefs. This is not to say that the apocalyptic message of the Book of Revelation should be used naively or in a fundamentalist way, but simply that the apocalyptic message must be critically and responsibly explored further in terms of the impact it can have in faith communities of today.

It is with this in mind that I make the choice to not discount the apocalyptic worldview where its impact on, and implications for, a performative reading are concerned.

Being a people of faith means daring to be identifiably different, which often results at least in opposition, and often in persecution and oppression (Jones \& Sumney 1999:26). This feeling of oppression, of being held back and kept unfulfilled, draws the group together for mutual support and consolation. It also motivates the members to accept the radical claim laid upon them by the God of apocalyptic thought (Jones \& Sumney 1999:26). The community of faith 
could interpret this danger and oppression as a sign of God's disfavour. Yet, whilst apocalyptic thought makes ample room for God's judgement, the troubles that beset the community of faith do not result from that (Jones \& Sumney 1999:27). Rather, in the midst of its distress, the community remains beloved by God. Even when evil runs rampant in the surrounding society and the influences of that society bear down on the faith community, God keeps a watchful and caring eye on them (see e.g. the 'Isaiah Apocalypse' in Is 24:1-27:13; Dn 3; Mt 24:22; and Rv 8-11). Without doubt, the community lives in hard times, but they are not bereft of the presence and care of God.

This assurance of the presence and care of God flows from the conviction that there is more to life than meets the eye. That 'this is not all there is'. That there is power, goodness and justice beyond and above that seen and experienced in the world. This belief reflects not a naïve and romanticised notion that everything will work out for the best in the end, but an unshakable certainty that nothing can rival the ultimate sovereignty of God, whose plans and intentions transcend the limits of human experience and even human imagination (Jones \& Sumney 1999:29). In apocalyptic thought, when the bastions of goodness seem to have crumbled beyond recognition or repair, God remains sovereign, and thus 'a cosmic renewal occurs, or a golden age arrives, or the earth is transformed into a paradise' (Cook 1995:28). Neither the worst that bad people can do nor the best that good people can do limits what can happen; only God has that power and potential (Jones \& Sumney 1999:31).

This conviction that God can and will unveil power, goodness and justice as yet unseen must find some way from the heart and soul to the hands and feet. No one can truly embrace that conviction and do nothing - if it is felt, it must be lived (Jones \& Sumney 1999:32). What we believe about God should influence, form and shape what we do and think. In fact, it has been said that 'it is existentially impossible to believe in God's coming triumph and to claim [God's] Holy Spirit without a lifestyle that conforms to that faith' (Beker 1982:110). It is on precisely this type of assumption that the author of the Book of Revelation has chosen to reveal to his audience the bigger, cosmic picture behind their everyday experiences - through an embodied experience of the true magnitude of God's actions and plans, the author wishes to encourage and strengthen the Christian communities of his day to stand fast against all possible opposition.

\section{Apocalypse and ethics}

Only very few scholars of the apocalyptic genre have argued that apocalyptic literature has no concern for ethics because it has separated the kingdom of God from earthly realities (Jones \& Sumney 1999:21). As this view has it, apocalyptic, rather than being socially responsible, becomes preoccupied with the damnation of the oppressor or with blessings in another realm. Though this is a common perception about apocalyptic thought amongst non-specialists, most scholars reject this interpretation, and many assert that ethics is central to apocalyptic (Jones \& Sumney 1999:21). The expectation of judgement found in all apocalyptic implies that ethics is central even when it is not explicitly discussed. One of the primary reasons authors wrote apocalyptic texts was to encourage faithfulness to God and loyalty to the Law of God, even if it leads to death. All apocalypses are hortatory, with discourses that encourage ethical living and that specify what that means being common in apocalyptic texts (see e.g. Dn 1-6 and 2 Esd). Another indicator of the importance of ethics in this way of thinking is the way life in the messianic future is described - it is in accordance with God's Law and an expression of God's covenant with them, and thus is a blessing. Given the emphasis on judgement found in apocalyptic thought, it is not surprising that individual accountability is important (Jones \& Sumney 1999:22).

Some interpreters argue that the apocalyptic outlook leads to a 'passive ethic' - an ethic which encourages people simply to submit to persecution. Though some apocalyptic works for example, The Assumption of Moses - do recommend 'quietism', this seems to be against the general trend:

- The War Scroll (1QM) offers us a specific example of this way of thinking, as its author expects the community to be active participants in the end time battle.

- The Damascus Scroll (CD) has a clear concern for social justice (especially Chapter 1).

- Enoch also encourages social justice through its attention to issues involving money, the courts and the poor.

So apocalyptic does not entirely abandon the world to evil. The people of God are expected to act justly and to work for a more just world, even though the forces against them are overwhelming (Jones \& Sumney 1999:22). Most apocalyptic writings are seeking ways to make sense of their belief in a good, powerful and just God given their experience of the world as a place ruled by evil. They do this mainly by asserting that God will act soon in ways that decisively vindicate God's nature as they understand it. At the same time, they also want to encourage their readers to remain faithful to God in very difficult circumstances (Jones \& Sumney 1999:23). This reflects the heart of apocalyptic thought or belief (Käsemann 1969:108-111): belief that God shows no partiality calls for our impartiality; belief that the power of God finds its fullest expression in love calls for fewer acts of domination and many more acts of compassion; belief that God hears the cries of the oppressed and promises release calls for our acts of justice and liberation; and belief that God sends the gospel because of our need and not because of our merit calls for nothing less than a reordering of human relationships.

We must take care not to confuse this clarion call to respond to God with having the responsibility of completing God's work (Jones \& Sumney 1999:33). God will accomplish what God sets out to accomplish. Although God may bless humanity with an understanding of the divine will and purposes, fidelity to God means attempting to participate in what God is doing, not doing God's work in God's stead. In 
Revelation, for example, neither the seer nor the faith community creates the new heaven and earth envisioned in chapter 21. However, God holds both the seer and the community accountable for preparation in that new heaven and earth. At any given point in time, the faithful can and will lack the ability to thwart injustice, oppression and hatred. We can, however, believe in, be shaped by and work for God's vision of justice, liberation and love. Being people of faith means being accountable to that vision, accepting it as valid and true, and making it the yardstick by which we measure our attitudes and actions (Keck 1996:1-13). We must also take care to avoid literalism at this point - apocalyptic thought does not compel us to believe that God moves history toward some single, ultimate, once-and-for-all, catastrophic and cataclysmic denouement (Jones \& Sumney 1999:34). Whether or not 'the end' is near, there remains an ultimate reality, an end, to which apocalyptic thought holds us accountable. In the context of this discussion, asking the right questions means holding ourselves accountable to God's will and purposes as we understand them, measuring ourselves not by societal standards of success but by fidelity to the God revealed to us (see e.g. Mk 13:37; Rv 2:7, 11, 17, 29; $3: 6,13,22)$.

This brings us to the theological centre of Christian apocalyptic thought - the life and ministry of Jesus the crucified, resurrected and enthroned Christ (Jones \& Sumney 1999:34). We see this clearly in the vision of the throne room narrated in Revelation 5. In this vision, a heavenly elder assures the seer that only 'the Lion of the tribe of Judah, the

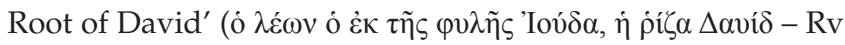
5:5) can open the scroll in the hand of God. Then the seer beholds in the throne room 'a Lamb standing as if it had been

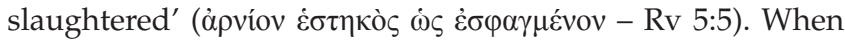
this Lamb takes the scroll from the hand of God, the heavenly beings twice sing praises that describe the Lamb as worthy because it was slaughtered ('A $\xi 10 \varsigma$ عĩ, 'you are worthy', in Rv

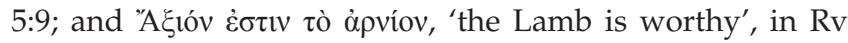
5:12). The Lamb was slain and crucified, but the fact that the Lamb now stands in heaven makes it obvious that he was resurrected as well, and the rest of the book makes it equally clear that God entrusts the control of history to this Lamb

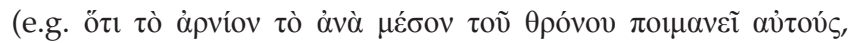
'because the Lamb at the center of the throne will be their

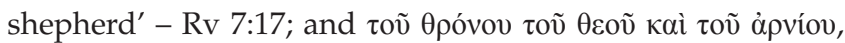
'from the throne of God and the Lamb' - Rv 22:1 and 3). The Jesus of Revelation is crucified, resurrected and enthroned. The Jesus of Christian apocalyptic thought is crucified because crucifixion indicates that evil is as powerful as it is pervasive. Christian apocalyptic thought thus forces us to see, even on the heavenly Lamb of God, the marks of slaughter - this reminds us of the cost and nature of our salvation. 'Resurrection cannot be celebrated if no one is dead' (Craddock 1986:275).

Thus, this genre within the Christian faith does not allow us to escape suffering - it clings to God by a thread called hope in the midst of, and despite, suffering. That thread expands and becomes a lifeline because this crucified Jesus is also resurrected. God, who is not limited to what we have yet seen and experienced, has an answer for the very worst humanity can do (Buttrick 1988:65). We dare to face oppression and rejection because the triumph of God revealed in Jesus shatters any defeat humans can muster. The enthroned Jesus completes the picture, for authority abides in the Lamb. The details of that glory may not be as clear to us as are those of the world around us, but that does not diminish our confidence that glory will come. Whereas we often attempt to reduce Jesus to a single, dominant characteristic (e.g. love) or a single purpose (e.g. salvation), apocalyptic thought considers him a symbol of the fullness

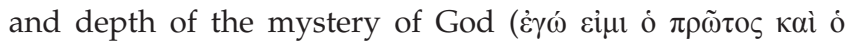

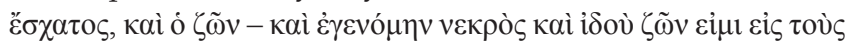

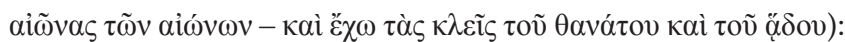

I am the first and the last, the living one. And though I was dead, behold, I am living unto the ages of ages. And I have the keys of Death and of Hades. (Revelation 1:17)

When we call Jesus 'Lord' (кúpıs), we declare that he rules in our lives and that his call to us and imperatives for us mean more than those of the would-be lords that beckon us, and that he demands and deserves our allegiance. We cannot accept the blessings of his ministry but reject his call to discipleship (Jones \& Sumney 1999:37). Because he is Lord, he established the ends and purposes to which God holds us accountable.

\section{Apocalypse as awakening}

Apocalyptic literature regularly features startling and unsettling images for the sake of awakening or revealing. These startling images alert us to two certainties (Jones \& Sumney 1999:38): (1) the awesome powers of evil will fall before the even more impressive power of God; and (2) the faithful play no part in this victory. Whether or not we like this symbolism, it challenges us to have confidence in the ability of God to defeat evil and to identify our task as remaining faithful in the face of evil. Apocalyptic literature risks making us uncomfortable by depicting a startlingly powerful God who does for us what we cannot do for ourselves, a God who inspires both awestruck devotion and trembling obedience (cf. Rowland 1998:506; Yarbro Collins 1996:16). The writers of apocalyptic literature insist that the conflict between the ways and rule of God and those that oppose God's ways and dominion has reached a level of intensity that God will not ignore, forcing a collision between the world that is and a world the writer imagines or anticipates (Jones \& Sumney 1999:39). In some places, apocalyptic writing provides an exaggerated picture of a heinously wicked world, in other places, it attempts to inspire and comfort the hearers with an idealistic picture of what the world will become. In both cases, the apocalyptic writer insists that the hearer make a decision as to where and in whom they will place their faith, challenging the faithful to look beyond the historical possibilities and decide to base their hopes and actions on the world of the vision. Although individuals must make this decision for themselves, apocalyptic thought focuses on the community more than on 
the individual (Jones \& Sumney 1999:40) - we hear the gospel, encounter resistance to the gospel and struggle to remain faithful to the gospel in the context of life in community.

Christian apocalyptic literature aims to nurture the church, console the church, chastise the church and hold the church accountable. It challenges the church as a whole to comfort and encourage the faithful to resist the ways and influence of the opponents of God and to bear witness to the promises and presence of God that transcend historical circumstances. Although each of us as individuals stands accountable to God, we are neither faithful nor apostate alone. Similarly, the writer of apocalyptic literature views the evils faced by the faithful as systemic as well as personal - that is part of the reason for the emphasis on community. Apocalyptic thought calls individuals and communities to a decision, it places the emphasis on bearing witness to what God has revealed and not on proving the veracity of that witness.

\section{The drama of apocalypse}

The persuasive power behind apocalyptic literature lies not in an appeal to scriptural exegesis or rational deduction, but rather in the authority of the seer and the revelation received (Murphy 1996:3). The apocalyptic writer does not attempt to convince hearers that he or she is right as much as the writer seeks to include the hearer in the unfolding drama of what God is doing in the world. As human beings can do nothing to hasten or delay the activity of God, the focus is on response. People can either prepare for and, as far as they are able, participate in God's revealed intent, or ignore the message revealed. Bluntly stated, people can have faith or refuse to have faith. The opening verses of Revelation illustrate this aspect of apocalyptic literature well (Rv 1:1-3) - the seer has the task of bearing witness and the hearers have the task of responding. As the visions of Revelation unfold, the seer describes, envisions, reports, recounts and narrates, and, in doing so, encourages, exhorts, warns and advises, but does not prove. Apocalyptic literature thus challenges us to respond to that which lies beyond proof, to believe what we have yet to understand clearly, to play with an image until it holds us within its grasp and awakens us to unseen presence and possibility and to encounter a mystery so deep that it demands that we be more than we have ever been and gives us hope beyond any we have ever had (Brueggemann 1998:195-212). The message of the apocalyptic writer, like nearly every blessing of faith, is too important for proof - it must be accepted, welcomed and lived.

In apocalyptic thought, evil cannot be ignored (Jones \& Sumney 1999:42). The injury inflicted on God's creation and the oppression experienced by those faithful to God defy explanation or comprehension, yet the apocalyptic writer is consumed not with evil, but with God. Although the apocalyptic writer takes sin and its consequences seriously, they regularly break forth in praise of God because the writer lives with the absolute conviction that something indeed will be done - God will prevail. Such songs of praise frequently find their way into the narrative. No matter how heinous the events described, worship of God continues. In the face of the worst that humanity does, and regardless of what humanity does, the worship of God continues. When evil seems invulnerable and when evil lies in ruins, worship of God continues. Apocalyptic thought always offers praise to God, for worship lies at the heart of who believers are (Jones \& Sumney 1999:42-43). This is because, as we cannot defeat evil, we must depend on God. Even at our best, we leave something to be desired and we need God. God deserves worship. Ultimately only God is, only God matters, only God lays legitimate claim on our lives, and only God deserves our allegiance and devotion. The apocalyptic writer will not let us forget that, regardless of what is or will be, the faithful have reason to praise God. The apocalyptic preacher will offer that praise whether we do or not.

\section{The nature of God in apocalypse}

The topic of the nature of God is not a common one in apocalyptic writings, but two characteristics of God stand out as very important for this way of thinking (Jones \& Sumney 1999:15-19).

\section{Sovereignty}

Belief in the sovereignty of God is essential for apocalyptic, as one of the main points of apocalyptic writings is to assure the readers that, in spite of evidence to the contrary, God is sovereign. We see this in the confidence these writers have that the plan of God is moving forward, and it is further demonstrated in the extensive ex eventu prophecy found in some apocalyptic writings. These elements of apocalyptic discourse, elements that are evidence for a historical determinism, show that these writers believe that history (at least in its main outline and final outcome) has been ordained and arranged by God. The certainty of God's victory is central to apocalyptic thought, found especially clearly in Daniel $4: 17,25-26,34$; and 7-12. This point is important in apocalyptic writings because the writers and readers seem to be living in a world that is ruled by evil and in which God is not sovereign. In fact, most apocalyptic thinkers are convinced that the world is currently not ruled by God. Yet this current domination of the world by evil is temporary - even though the world is presently ruled by the forces of evil, the true sovereign of the entire cosmos will soon act. The God who is the ultimate King will reclaim what rightfully belongs to God and will punish the usurpers and reward those who have been faithful to God. Without such a belief in the sovereignty of God, apocalyptic - indeed, all Christian faith - cannot exist.

\section{Justice}

Apocalypticists also believe that God is just. Belief in the justice of God is another primary motivation for apocalyptic thought; for the fact that the world is ruled by evil and that the righteous are those who suffer most are problems only if one believes God is just. So apocalyptic seeks ways to show that God's justice will be exercised and will be the final 
word - an idea manifested in the development of the ideas of judgement after death and of the resurrection. Judgement is a central characteristic of apocalyptic thought, and at the heart of all apocalyptic speculation about judgement is the conviction that God will not let God's people be destroyed by their enemies. Thus, judgement is necessarily related to their belief in the justice of God because, for justice to reign, evil must be punished and good must be rewarded (see e.g. $1 \mathrm{En}$. 102:1; 103:1-104:8).

So, in the face of persecution, the ethical faiths of Judaism and Christianity opted for the belief that God's righteousness is exercised in a realm beyond this earthly life with judgement being based on morality. In Judaism, this meant faithfulness to the Law. In Christianity, it meant adhering to Christian morality as understood in a particular community, and not denying that faith in persecution. It was exactly this belief in the justice of God that led to the belief in the resurrection of the dead within Judaism. But it was the events associated with the Maccabean revolt that finally resulted in a fairly widespread belief in the resurrection of at least some of the dead; for such terrible events (e.g. 4 Macc 7), of course, push the question of the justice of God to the forefront. So belief in a resurrection that included judgement grew out of the injustices experienced by communities that held firmly to their belief in a sovereign and just God. One would think that judgement based on morality requires that apocalypticists be legalists, but that is far from the case. Only a few apocalyptic writings (e.g. 3 Bar.) assert that judgement is based solely on one's deserts. Most acknowledge that people are found righteous in judgement only through God's grace and mercy as being necessarily cooperative but equally necessary (see e.g. 1QM 11; and 2 Esd). Thus, when apocalypticists think of judgement, fear is not their first thought. They certainly do not lose sight of the accountability judgement brings to them, but they trust God to fulfil his purposes and nature by bringing them into the place God has prepared for God's people.

The idea of God being just in judgement makes modern people nervous. We are more ready to focus our attention on God's love and mercy, thinking that these are the opposite of justice. But the alternative to God being just is that God is unfair - that God plays favourites or is capricious. This unhappy alternative would mean we could never trust God. Furthermore, the justice of God is the basis for all Christian calls for justice in the world. As Christian ethics is based on the character of God, we have no basis for working for justice unless we believe in the unshakable justice of God. So apocalyptic brings us back to a characteristic of God with which we are less than comfortable, but which is essential to who God is and to what makes God a God we can trust and a God who is worthy of worship.

\section{The Apocalypse as challenge}

The writer of the Book of Revelation clearly had an intention, which was to effect change in the audience and readers - to strengthen their faith and to keep them loyal in times of persecution. Yet the visions are sufficiently ambiguous to leave themselves open for further interpretation. John may have understood them to refer both to specific events that he expected to happen in his own time, and to events of a less definite nature in an undetermined future. Because of this open-ended quality, his visions are capable of many interpretations. It is this openness of the book that makes it relevant for every generation. Underlying the book's lack of clarity is a challenge. As there are many possible fulfilments of the various prophecies, the Apocalypse invites us to consider which individuals or institutions function as the beast for us and claim from us the devotion and allegiance that are, fittingly, only given to God. This consideration is meant to be understood and used for self-examination and not in a purely polemical way, for that would be destructive.

The possibility of more than one meaning challenges us to consider whether an ideal state of affairs can be realised now, or must await us in the future. If it is even in a small measure present now, it is evidence of God's grace in action. If it can be a reality in the future, the promise is nurture for hope. In the setting of worship, the mysteriousness of the Apocalypse is entirely appropriate. The book evokes a sense of the transcendence of God. The strangeness of its symbols conveys the notion of a realm that is beyond human understanding. In poetical power, it exceeds all other New Testament writings. For centuries, its pictures of heaven have provided material for praise and adoration. This is because the Apocalypse affirms God's sovereignty and the ultimate fulfilment of God's purpose. In this way, it offers strong support to individuals in maintaining their faith. It is a book for the Christian, the church and the world. To those who share its faith, though they may not hold it in precisely the same form as its author, it gives assurance of the victory of God and the triumph of the Lamb.

\section{Keeping the first century in mind}

In antiquity, all religious life was fundamentally determined by ritually ordered cultic worship, which was thus a central element in the formation of every symbolic universe and the meaning of life itself (Schnelle 2009:751). It is important to see the Book of Revelation in the particular historical context of the believing community which created it because Christianity and its documents and doctrines relate to specific moments of history (Court 2000:7). According to Charpentier (1982:105), 'the Book of Revelation, the Apocalypse, is a book of fire and blood in the image of our world'. This view suggests a sense of realism and of urgent relevance, just as people have found that experience of wartime or of catastrophe sends them back to these words of prophecy. In such circumstances, the most important question is how one should read the book. There are three main things to consider (Court 1994:23):

- We must be aware of the situation in which the book came into being - in a small Christian group, politically vulnerable and persecuted for its faith.

- It must be read imaginatively in a way that is responsive to the writer's images and use of symbolism - this means 
enjoying the sound of the words themselves and relating the verbal pictures to the reader's memory.

- Perhaps, most importantly, we must recognise the author's theological priorities - the relationships of this world with the world to come, of the church with the crucified and risen Lord and of the Son with the Father who is the world's creator.

All these are vital connections in the structure of the Apocalypse. But it is also important to see the book as a visionary interpretation of the church and its future. Here we need to give full weight to the ideas and images contained in its visions. The complementarity of different approaches historical, literary and psychological - is vital for a modern understanding (Court 1994:18-21). As has been accentuated throughout this article, Revelation is an apocalypse. As such, Revelation was never meant to be taken literally. But we should take Revelation seriously, for it shows a relationship between pain, martyrdom and Christian belief. And it clearly depicts a continuity between past, present and future for the church and the individual believer, from which the disillusioned churches of today can learn (Court 2000:7).

The Book of Revelation focuses on exhortation, which stresses the importance of standing firm in faith and love, and enduring tribulation (Court 2000:10). This exhortation is reinforced by eschatological threats and promises. The Christian Apocalypse consoles those who glimpse what hell can be, and encourages those who would build a New Jerusalem (Court 1994:11). On this basis, the Revelation of John develops an impressive sacral architecture - by presenting a heavenly reality within the framework of an apocalyptic vision of history, it provides a new interpretation for earthly events and experiences. The author develops a theology in visionary pictures of the cultic reality in heaven and on earth, aiming to strengthen the threatened identity of his churches, and to orient it by this new symbolic universe. At the same time, this cultic thought world grants participation in the event itself (Schnelle 2009:751).

\section{The performative relevance of Revelation for today}

As in John's time, so too today those who suffer unjustly - the victims of contemporary oppressive political powers and social inequalities - cry out for justice and liberation (Boesak 1987:38; Richard 1995:3; Schüssler Fiorenza 1981:11). But we will not be able to perceive their vision unless we also share the theological analysis of those who experience our culture, society and (even) church as destructive. Oppressive political-societal-religious powers and the life-giving empire of God cannot co-exist (Boesak 1987:38; Richard 1995:3; Schüssler Fiorenza 1981:32). John's attempts to formulate the reality and meaning of eschatological salvation in universal and political symbols again gains greater significance at a time when those who share the author's experience of oppression and exploitation attempt to formulate their own theology of liberation and to stake their life on it (Boesak 1987:38; Richard 1995:3; Schüssler Fiorenza 1991:128).
Although Revelation's world of vision is articulated in cultic language, such language serves to symbolise the struggle between divine and imperial power, seeking to move its audience to action (DeSilva 2004:885, 906-908; Schüssler Fiorenza 1991:129).

As has been demonstrated, this move towards action is not about an intellectual response but about emotional reactions and religious commitment. Revelation thus provides this vision of an alternative world in order to motivate the audience and strengthen their resistance in the face of Babylon or Rome's overwhelming threat to destroy their life and livelihood. This makes them theoethical in nature. Thus Revelation engages in a radical ethical dualism that places before the audience an 'eitheror' decision: either one succumbs to the oppressive world power of Babylon or Rome and its religious legitimisation, or one engages in the struggle for God's qualitatively new cosmopolis that is free from all oppression and evil (Boesak 1987:38; Richard 1995:3; Schnelle 2009:752-754; Schüssler Fiorenza 1991:130). Revelation's narrative symbolisation represents one response amongst other competing voices, as persuasive argument becomes necessary in a situation where different possibilities for action exist (Schüssler Fiorenza 1991:132). Very important to remember here is that it is only when a rhetorical situation similar to that addressed by Revelation exists, that Revelation's world of vision can be understood as a 'fitting' theo-ethical response (Boesak 1987:38; Richard 1995:3; Schüssler Fiorenza 1991:139). Where such a situation does not persist, the rhetorical power of John's vision does not engender resistance but rather evokes resentment or projects evil onto others (Schüssler Fiorenza 1991:139).

I conclude with performative texts from the Apocalypse. Revelation 1:5-6 quotes a traditional baptismal formula which stresses that, by his blood, Christ has freed the baptised from their sins and installed them to kingship, making them priests for God. In Revelation 5:9-10's 'new song', this anthropological understanding of redemption and salvation is modified by expressing it in theological, socio-political language (Schüssler Fiorenza 1998:76). The author no longer speaks of redemption from personal sins, but of the ransom of slaves from the whole world. As such, they are the antikingdom to the Roman Empire. By underlining this eschatological aspect of salvation, the author emphasises the imperative that must follow the indicative of Christian existence - only those who, like Christ, were faithful witnesses and have been victorious in their struggle with the Roman Empire will have a part in the eschatological kingship and priesthood. This is because final salvation is only possible when God and Christ have assumed the power and kingship on a new earth, in a new world, where death no longer exists (Rv 21:4).

So, according to Revelation, fully realised redemption and salvation presupposes not only the liberating and dignifying of individual persons but also the creating of a new world. It seeks to persuade and motivate by constructing a 'symbolic 
universe' that invites imaginative participation (DeSilva 2004:905-908, 912-923; Du Rand 2007:24-25, 34-35, 45-47; Schnelle 2009:751-754, 761-768; Schüssler Fiorenza 1998:187). The strength of Revelation's persuasion for action is to be found in the 'evocative' power of its symbols as well as its hortatory, imaginative, and emotional language and dramatic movement. They provide the vision of an 'alternative world' in order to encourage Christians and to enhance their staying power.

If the human story is to be a comedy rather than a tragedy then, it seems, it will have to be a divina commedia. The immanent will not be able to drag itself by its own bootstraps out of the tragic mire which seems, according to all the evidence, to be the human lot. Here we are forced to reckon with a 'wager on transcendence' - not on a vertical transcendence, but with a transcendent God whose way of being transcends ours and our world, in the present moment. On a horizontal transcendence, and on a God who faithfully awaits us beyond the very end of history itself. Revelation represents a 'fiction of improbable resolution' (Bauckham \& Hart 1999:50), with the improbable resolutions rooted in factors and possibilities lying beyond those apparent within the story itself. We have to wager on a God whose capacities are such as to fashion out of our tragic endings (both individually and collectively) a future which wholly transcends the potential latent within history. Within the story which the author of the Apocalypse of John tells us about the destiny of our world, just such a 'wager' is to be found - this wager is more familiarly referred to as faith in the God of the resurrection. Through this faith, our imagination is engaged, stretched and enabled to accommodate a vision of a meaningful and hopeful future for the world that automatically leads to significant doings.

\section{Acknowledgements}

This article is based on ideas first explored in my DTh thesis - Ritual functions of the Book of Revelation: Hope in dark times - obtained in 2016 from the University of South Africa under the supervision of Prof. P.J.J. Botha in the Department of New Testament and Early Christian Studies (now a unit within the larger Department of Biblical and Ancient Studies).

\section{Competing interests}

The author declares that they have no financial or personal relationships that may have inappropriately influenced them in writing this article.

\section{Author's contributions}

H.J.v.R. is the sole author of this research article.

\section{Ethical considerations}

This article followed all ethical standards for research without direct contact with human or animal subjects.

\section{Funding information}

This research received no specific grant from any funding agency in the public, commercial or not-for-profit sectors.

\section{Data availability}

Data sharing is not applicable to this article as no new data were created or analysed in this study.

\section{Disclaimer}

The views and opinions expressed in this article are those of the author and do not necessarily reflect the official policy or position of any affiliated agency of the author.

\section{References}

Aune, D.E., 1997, Word biblical commentary 52A: Revelation 1-5, Word Books, Dallas, TX.

Aune, D.E., 2005, 'Understanding Jewish and Christian apocalyptic', Word \& World 25(3), 233-245

Aune, D.E., 2006, 'The Apocalypse of John and Palestinian Jewish apocalyptic' Neotestamenica 40(1), 1-33.

Austin, J.L., 1962, How to do things with words, Harvard University Press, Cambridge, MA.

Barr, D.L., 2010, 'The Apocalypse of John', in D.E. Aune (ed.), The Blackwell companion to the New Testament, pp. 632-651, Blackwell Publishing Ltd., Oxford.

Bauckham, R., 1993, The climax of prophecy: Studies on the Book of Revelation, T \& T Clark, Edinburgh.

Bauckham, R. \& Hart, T., 1999, Hope against hope: Christian eschatology in contemporary context, Darton, Longman and Todd Ltd, London.

Beker, C.J., 1982, Paul's apocalyptic gospel: The coming triumph of God, Fortress Press, Philadelphia, PA.

Boesak, A., 1987, Comfort and protest: The Apocalypse from a South African perspective, Westminster Press, Philadelphia, PA.

Britannica, 2006, Apocalypticism, Encyclopaedia Britannica, viewed 21 April 2021, from https://www.britannica.com/topic/apocalypticism.

Brown, R.E., 1997, An introduction to the New Testament, Doubleday, New York, NY.

Brueggemann, W., 1998, 'Preaching a sub-version', Theology Today 55(2), 195-212. https://doi.org/10.1177/004057369805500205

Buttrick, D.G., 1988, Preaching Jesus Christ: An exercise in homiletic theology, Fortress Resources for Preaching, Fortress Press, Philadelphia, PA.

Charpentier, E., 1982, How to read the New Testament, SCM Press, London.

Cohn, N., Edwards, M.E. \& Campion, N., 2014, 'Apocalypticism explained: Nazism \& Marxism', Frontline, viewed 21 April 2021, from https://www.pbs.org/wgbh/ pages/frontline/shows/apocalypse/explanation/marxism.html.

Cook, S.L., 1995, Prophecy and apocalypticism: The postexilic social setting, Fortress Press, Minneapolis, MN.

Court, J.M., 1994, Revelation, New Testament Guides, Sheffield Academic Press, Sheffield.

Court, J.M., 2000, The Book of Revelation and the Johannine apocalyptic tradition, JSNT Supplement Series 190, Sheffield Academic Press, Sheffield.

Craddock, F.B., 1986, 'Preaching the Book of Revelation', Interpretation 40(1), 270-282. https://doi.org/10.1177/002096438604000305

DeSilva, D.A., 2004, An introduction to the New Testament: Contexts, methods \& ministry formation, Intervarsity Press, Downers Grove, IL.

DiTommaso, L., 2019, Apocalyptic thought after Revelation, Bible Odyssey, viewed 21 April 2021, from https://www.bibleodyssey.org/en/passages/related-articles/ apocalyptic-thought-after-revelation.

Du Rand, J., 2007, Die A-Z van Openbaring: 'n Allesomvattende perspektief op die Boek van Openbaring, Christelike Uitgewersmaatskappy, Vereeniging.

Enroth, A-M., 1990, 'The hearing formula in the Book of Revelation', New Testament Studies 36(4), 598-608. https://doi.org/10.1017/S0028688500019755

Farrer, A.M., 1949, A rebirth of images: The making of St John's Apocalypse, Dacre Press, Westminster.

Greydanus, S.D., 2019, The secular apocalypse: Irreligion, pop culture and the end of the world, National Catholic Register, viewed 21 April 2021, from https://www. ncregister.com/features/the-secular-apocalypse-irreligion-pop-culture-and-theend-of-the-world.

Guthrie, D., 1987, The relevance of John's Apocalypse, Paternoster Press, Grand Rapids, MI.

Hagner, D.A., 2012, The New Testament: A historical and theological introduction, Baker Academic, Grand Rapids, MI. 
Horsley, R.A., 2011, 'Oral communication, oral performance, and New Testament interpretation', in A.B. McGowan \& K.H. Richards (eds.), Method and meaning interpretation, in A.B. McGowan \& K.H. Richards (eds.), Method and meaning:
Essays on New Testament interpretation in honor of Harold W. Attridge, Essays on New Testament interpretation in honor
pp. 125-155, Society of Biblical Literature, Atlanta, GA.

Jones, L.P. \& Sumney, J.L., 1999, Preaching apocalyptic texts, Chalice Press, St. Louis, MO.

Käsemann, E., 1969, New Testament questions of today, Fortress Press, Philadelphia, PA.

Keck, L.E., 1996, 'The accountable self' in E.H. Lovering \& J.L. Sumney (eds.), Theology and ethics in Paul and his interpreters: Essays in honour of Victor Paul Furnish, pp. 1-13, Abingdon Press, Nashville, TN.

Keen, S., 2007, 'A secular apocalypse', Bulletin of the Atomic Scientists 63(1), 29-31. https://doi.org/10.2968/063001009

Knight, J., 1999, Revelation, Readings: A new biblical commentary, Sheffield Academic Press, Sheffield.

Maier, H.O., 2002, Apocalypse recalled: The Book of Revelation after Christendom, Fortress Press, Minneapolis, MN.

Malina, B.J. \& Pilch, J.J., 2000, Social-science commentary on the Book of Revelation, Fortress Press, Minneapolis, MN.

Mathewson, D.L., 2010, Verbal aspect in the Book of Revelation: The function of Greek verb tenses in John's Apocalypse, Brill, Leiden.

Moore, S.D., 1995, 'The beatific vision as a posing exhibition: Revelation's hypermasculine deity', Journal for the Study of the New Testament 60(4), 27-55. https://doi.org/10.1177/0142064X9601806002

Murphy, F.J., 1996, 'Introduction to apocalyptic literature', in L.E. Keck (ed.), The new interpreter's Bible VII. Introduction to apocalyptic literature: Daniel, the Twelve Prophets, pp. 1-16, Abingdon Press, Nashville, TH.

Pilch, J.J., 1978, What are they saying about the Book of Revelation? Paulist Press, New York, NY.

Pippin, T., 1999, Apocalyptic bodies: The biblical end of the world in text and image Routledge, New York, NY.

Prévost, J-P., 1993, How to read the Apocalypse, SCM Press Ltd., London.
Richard, P., 1995, Apocalypse: A people's commentary on the Book of Revelation, Bible and Liberation, Orbis, Maryknoll, New York, NY.

Rowland, C., 1998, 'The Book of Revelation: Introduction, commentary, and reflections', in L.E. Keck (ed.), The new interpreter's Bible XII. Hebrews, James, 1 and 2 Peter, 1, 2, and 3 John, Jude, Revelation, pp. 501-743, Abingdon Press, Nashville, TN.

Royalty, R.M., 1998, The streets of heaven: The theology of wealth in the Apocalypse of John, Mercer University Press, Macon, GA.

Schnelle, U., 2009, Theology of the New Testament, Baker Academic, Grand Rapids, MI.

Schüssler Fiorenza, E., 1981, Invitation to the Book of Revelation: A commentary on the Apocalypse with complete text from the Jerusalem Bible, Image Books, Garden City, NY.

Schüssler Fiorenza, E., 1991, Revelation: Vision of a just world, Fortress Press, Minneapolis, MN.

Schüssler Fiorenza, E., 1998, The Book of Revelation: Justice and judgement, Fortress Press, Minneapolis, MN.

Searle, J., 1969, Speech acts: An essay in the philosophy of language, Cambridge University Press, Cambridge.

Tabor, J., Boyer, P. \& Collins, J.J., 2014, 'Apocalypticism explained: The apocalyptic world view', Frontline, viewed 21 April 2021, from https://www.pbs.org/wgbh/ pages/frontline/shows/apocalypse/explanation/worldview.html.

Thompson, M., 1985, 'Future tense: An analysis of science fiction as secular apocalyptic literature', Master's thesis, Department of Religious Studies, University of Cape Town.

Vox, L., 2017, Secular vs. Scientific Apocalypticism, University of Pennsylvania Press, viewed 21 April 2021, from https://pennpress.typepad.com/pennpresslog/ 2017/07/secular-vs-scientific-apocalypticism.html.

Wainwright, A.W., 1993, Mysterious apocalypse: Interpreting the Book of Revelation, Abingdon Press, Nashville, TN.

Yarbro Collins, A., 1996, Cosmology and eschatology in Jewish and Christian apocalypticism, Brill, Leiden. 